\title{
Response of Canola (Brassica napus L.) to Biofertilizers under Egyptian conditions in newly reclaimed soil
}

\author{
Ekram A. Megawer and Salem A. Mahfouz* \\ Agronomy Dept., Fac. Agric. Fayoum, Egypt \\ *Microbiology Department, Fac. Agric. Fayoum, Egypt, salmahfouze@yahoo.com
}

\begin{abstract}
The study was conducted in the farm of Faculty of Agriculture, Demo, Fayoum, Egypt. The soil was of loamy- sand type. During 2006/2007 and 2007/2008 season, using a split plot arrangement in randomized complete block design with three replicates, the work was done to determine the effect of adding biofertilizers (Azotobacter + Azospirillum, free nitrogen fixers and Trichoderma a phosphate solubilizing fungi) in combinations with mineral $\mathrm{N}$ fertilizer with either recommended dose $\left(\mathrm{N}_{1}\right)$ or half of this dose $\left(\mathrm{N}_{2}\right)$ on yield quantity and quality of two canola lines $\left(\mathrm{L}_{6}\right.$ and $\left.\mathrm{H}_{2}\right)$. The results revealed that the two canola lines were significantly different in plant height, number of branches, number of pods and seed yield /plant. $\mathrm{L}_{6}$ surpassed $\mathrm{H}_{2}$ line for previous traits, in addition to insignificantly higher values of the other traits; $T_{10}, T_{11}$ and $T_{12}$ showed superiority and high productivity with saving half of the mineral $\mathrm{N}$ recommended dose. For interaction; $\mathrm{H}_{2} \mathrm{~T}_{10}$, was the best in all traits except for plant height, protein and oil percentages. $\mathrm{H}_{2} \mathrm{~T}_{4}, \mathrm{~L}_{6} \mathrm{~T}_{6}$ and $\mathrm{L}_{6} \mathrm{~T}_{8}$, for all traits except for seed index and oil percentage. The highest productivity recoded by $\mathrm{H}_{2} \mathrm{~T}_{10}\left(\mathrm{~N}_{2}+\right.$ Trichoderma + Azotobacter $), \mathrm{H}_{2} \mathrm{~T}_{11}\left(\mathrm{~N}_{2}+\right.$ Azotobacter+ Azospirllum) and $\mathrm{L}_{6} \mathrm{~T}_{8}\left(\mathrm{~N}_{2}+\right.$ Azotobacter) which outyielded their corresponding control by 39.3, 31.8 and $23.0 \%$ a result of using only $50 \%$ of the recommended dose of $\mathrm{N}$-fertilizer $\left(\mathrm{N}_{2}\right)$. The latter combination was also superior in protein content $(26.5 \%)$. These three combinations could be recommended as alternative method for canola fertilization, where they had economic and safely advantages.

Keywords: Canola, Lines, Yield, Azotobacter, Azospirillum and Trichoderma
\end{abstract}

\section{Introduction}

Canola (Brassica napus L.) is one of the main oil crops in many countries especially in Canada, European Union and USA. Cultivation of canola in Egypt may provide an opportunity to overcome some of the local deficit of vegetable edible oil production, particularly it could be successfully grown during winter season in newly reclaimed land outside the old one of Nile valley to get-arround the competition with other crops occupied the old cultivated area. (Kandil, 1984; Sharaan, 1986; Ghallab and Sharaan (2002) and Sharaan et al., 2002). Suitability of growing canola under Egyptian conditions, compared with other oil crops, may be ascribed to its tolerance to harsh environmental influences frequently prevailing in such newly reclaimed soil such as salinity and drought (Weiss, 1983). Oilseed rape has a relatively high requirement of nitrogen where the content of this nutrient in seeds and plant tissues is greater than in most grain crops. Research on $\mathrm{N}$ efficiency in oilseed rape was initiated by Grami and La Croix (1977) in Canada. Since Canola is considered as a nitrogen demanding crop, the addition of $60 \mathrm{~kg} / \mathrm{feddan}$ nitrogen under Egyptian conditions increased its yield (Kandil, 1984). However, the higher application of mineral nitrogen fertilizers may lead to environmental pollution especially to groundwater, and soil acidification as well as increased denitrification resulting in higher emission of $\mathrm{N}_{2} \mathrm{O}$ to the atmosphere which may impact global warming. So, the need to find alternatives was crucial. Soil microorganisms, viz. Azotobacter and Azospirillum as $\mathrm{N}_{2}$-fixing bacteria could be a beneficial source to enhance plant growth and producing considerable amounts of biologically active substances that can promote growth of reproductive organs and increase its productivity (Sharma et al.1997; Khalid et al. 2004; Rodriguez et al. 2004; Ebrahimi et al. 2007, Yasari et al. 2008 and Yasari et al. 2009). Not much experimental work has been conducted on the use of such $\mathrm{N}_{2}$-fixing and phosphate solubilizing microorganisms bacteria on the growth and yield of Canola. The only attempt made on canola refer to the application of inoculation with Penicillum bilaji, Bacillus thuringiensis and phosphate solubilizing Rhizobacteria for the P-uptake, vegetative growth and grain yield of Canola was performed by Freitas et al. (1997). Significant and positive effect on plant height and yield of Brassica plant after using Azotobacter was recorded by Gupta and Samnotra (2004) \& Prasad and Prasad (2004). Finding alternative application for reducing the harmful effect of mineral $\mathrm{N}$-fertilizers with maintaining the high yield production for canola especially in newly reclaimed soil which is considered poor in nutrients' content and microorganisms became the must. The aim of this study was directed to investigate the effect of Azotobacter and Azospirillum as free-living nitrogen fixers and Trichoderma as phosphate solubilizing fungi in combinations with mineral $\mathrm{N}$ fertilizer on the productivity of some canola lines in the newly reclaimed soil.

\section{Materials and Methods}

The experiment has been conducted in two successive seasons the farm of the Faculty of Agriculture, Demo Research Station, Fayoum University, Egypt. The soil was of loamy-sand type, with $\mathrm{pH} 7.43, \mathrm{EC}\left(\mathrm{dsm}^{-1}\right) 8.55, \mathrm{Ca}^{++} 0.91$, $\mathrm{Mg}^{++} 0.45, \mathrm{Na}^{+} 1.76, \mathrm{~K}^{+} 0.04, \mathrm{HCO}_{3} 0.07, \mathrm{Cl}^{-}$ 
$1.72, \mathrm{SO}_{4} 1.25, \mathrm{CaCO}_{3} 12.72 \%$, organic matter $0.54 \%$ and Total N $0.25 \%$. The study aimed to answer the question; to what extent the yield quantity and quality of the canola lines affected by combination between mineral and biofertilizers under the conditions of newly reclaimed soil?. During the field preparation, $15 \mathrm{~kg} / \mathrm{feddan}$ superphosphate $\left(15.5 \% \mathrm{P}_{2} \mathrm{O}_{5}\right)$ were added. Potassium sulphate $\left(48.5 \% \mathrm{~K}_{2} \mathrm{O}\right.$ at the rate of $50 \mathrm{~kg} / \mathrm{feddan}$ was added immediately before the $1^{\text {st }}$ irrigation. The cultivation was carried out on 20/11/2006 and 22/11/2007 seasons, respectively using a split-plot arrangement in randomized complete block design, with three replications. The main plots contained canola lines and the fertilizer combinations were in the sub-plots. Each replicate contained 26 plots, and the plot area was $10.5 \mathrm{~m}^{2}$. Inoculated seeds of each treatment $(T)$ were planted in hills, $10 \mathrm{~cm}$ apart within rows of $30 \mathrm{~cm}$ distance between them. Other cultural practices recommended for growing canola were followed.

Seeds: The seeds of the two used lines of Canola (Brassica napus L.) were kindly provided from Agronomy Dept., Fac .Agric, Fayoum, Egypt (Breeding Program, Ghallab and Sharaan; 2002). The two lines were; line 6 $\left(L_{6}\right)$, a selected line (Drakkar variety, Germany) and $\mathrm{H}_{2}$ (selected line originated to crossing between Canola104 and Hanna, Egypt).

\section{Isolation of free nitrogen fixers (FNF) and phosphate dissolving fungi:}

Soil samples were collected and subjected to serial dilutions on Day and Dobereiner (1975) medium; modified Ashby medium (Hegazi et al.1980) and Bunt and Rovira (1955) medium for the isolation of Azospirillum, Azotobacter and Trichoderma, respectively.

\section{Prepration of Inocula:}

After growth, colonies were purified and the isolates were identified to the genus level. FNF were grown on the same isolation medium but in liquid form and spore suspension for Trichoderma was prepared on Tween-80 broth. The isolates were left on shaking till each $\mathrm{ml}$ will contain $10^{7}-10^{8} \mathrm{cfu} \mathrm{g}^{-1}$ and each $\mathrm{ml}$ of Tween broth contained $10^{4} \mathrm{spore} / \mathrm{ml}$. The seeds were mixed with equal amounts of the suspensions in addition to $10 \%$ Arabic gum to confirm the attachment of cells and spores on seeds surface, spread and air-dried before planting.

Fertilizers' combinations: Both the recommended dose of the $\mathrm{N}$-fertilizer, $60 \mathrm{~N}$ units/feddan $\left(\mathrm{N}_{1}\right)$ where the feddan $=0.42$ hectare and half of this dose $\left(\mathrm{N}_{2}\right)$ were used in combination with the biofertilizers (12 combinations + control) as follows:

- Recommended dose of nitrogen + Trichoderma $=\mathrm{N}_{1}+$ Tri. $\left(\mathrm{T}_{1}\right)$
- Recommended dose of nitrogen + Azotobacter $=\mathrm{N}_{1}+$ Azot. $\left(\mathrm{T}_{2}\right)$

- Recommended dose of nitrogen + Azospirillum $=\mathrm{N}_{1}+$ Azosp. $\left(\mathrm{T}_{3}\right)$

- Recommended dose of nitrogen + Trichoderma+ Azotobacter= $\mathrm{N}_{1}+$ Tri. + Azot. $\left(\mathrm{T}_{4}\right)$

- Recommended dose of nitrogen + Azotobacter + Azospirillum = $\mathrm{N}_{1}+$ Azot.+Azosp. $\left(\mathrm{T}_{5}\right)$

- Recommended dose of nitrogen + Trichoderma+Azotobacter + Azospirillum = $\mathrm{N}_{1}+$ Tri.+ Azot.+Azosp. $\left(\mathrm{T}_{6}\right)$

- Half recommended dose of nitrogen + Trichoderma $=\mathrm{N}_{2}+$ Tri. $\left(\mathrm{T}_{7}\right)$

- Half recommended dose of nitrogen + Azotobacter $=\mathrm{N}_{2}+$ Azot. $\left(\mathrm{T}_{8}\right)$

- Half recommended dose of nitrogen + Azospirillum $=\mathrm{N}_{2}+$ Azosp. $\left(\mathrm{T}_{9}\right)$

- Half recommended dose of nitrogen + Trichoderma + Azotobacter $=$ $\mathrm{N}_{2}+$ Tri. + Azot. $\left(\mathrm{T}_{10}\right)$

- Half recommended dose of nitrogen + Azotobacter + Azospirillum= $\mathrm{N}_{2}+$ Azot. + Azosp. $\left(\mathrm{T}_{11}\right)$

- Half recommended dose of nitrogen + Trichoderma+ Azotobacter + Azospirillum $=$ $\mathrm{N}_{2}+$ Tri.+ Azot.+Azosp. ( $\left.\mathrm{T}_{12}\right)$

- Recommended dose of nitrogen $=$ Control $\left(T_{13}\right)$

The seeds were treated with bacteria and fungi before planting. The nitrogen was added in three quantities the first at planting, the second at the $1^{\text {st }}$ irrigation and the third at the $2^{\text {nd }}$ irrigation.

At harvesting time a sample of 10 plants were taken from each plot to measure the averages of plant height $(\mathrm{cm})$, number of branches/plant, number of pods and seed yield/plant. Seed index and seed yield/feddan $(\mathrm{kg})$ were determined on plot basis. Seed oil and protein percentages were measured following Nuclear Magnetic Resonance (NMR) and Micro Kjeldahl digestion using automated colorimetric analysis, respectively. Combined data for the two seasons were statistically analyzed following the analysis of variance technique (ANOVA) and then the mean differences were adjudged by Duncan's Multiple Range Test (Gomez and Gomez, 1984).

\section{Results and Discussion Effect of lines}

Results of combined data drawn in Fig.(1) show that the two canola lines were significantly different in plant height, number of branches, number of pods and seed yield /plant. $\mathrm{L}_{6}$ surpassed $\mathrm{H}_{2}$ line for the previous traits, in addition to it possessed insignificantly increases in the other traits. These results revealed that the well-developed $L_{6}$ line may be taken as an evidence for its high response to nitrogen and biofertilizer compared to $\mathrm{H}_{2}$ line. In this concern, Ebrahimi et al. (2007) reported 
that rapeseed varieties had different significant effects on number of branches, but nonsignificant effect on protein percentage. In addition, Yasari et al. (2008) reported that treatment canola with mineral and biofertilizer resulted in maximum seed yield coinciding with maximum number of pods/plant.

\section{Effect of applied different fertilizers' combinations}

Data presented in Table (1) reveal that all yield and quality traits were significantly different due to different fertilizers' combinations. Treatments; $T_{12}, T_{8}, T_{11}$ and $T_{6}$ for plant height (cm); 136.2, 135.5, 135.0 and 135.0, respectively were of height similar to that of control treatment. In this respect, similar results were previously recorded by Prasad and Prasad (2004). Whereas, $\mathrm{T}_{3}$ produced the shortest plant. $T_{10}, T_{4}, T_{11}$ and $T_{12}$ for number of branches; 7.2, 6.9, 6.8 and 6.7, respectively, surpassed the control and other treatments. $T_{6}$, $\mathrm{T}_{10}, \mathrm{~T}_{8}$ and $\mathrm{T}_{4}$ produced higher number of pods /plant; 356, 355.2, 340 and 313.6, respectively, than those of control and most of other treatments. $T_{4}, T_{3}, T_{10}$ followed by $T_{11}$ and $T_{2}$ gave heavier seed index $(\mathrm{g}) ; 3.15,3.14,3.09$, 2.98 and 2.96, respectively, than those of control and most of other treatments. In regard to seed yield/plant, although $T_{4}$ and $T_{6}$ which revealed full $\mathrm{N}$ dose possessed the highest values $(28.23 \& 27.55 \mathrm{~g}), \mathrm{T}_{10}$ and $\mathrm{T}_{8}$ which received half $\mathrm{N}$ dose produced comparable yields $(26.81 \& 26.05 \mathrm{~g})$. The superiority of these four treatments due to their highest number of pods/plant. $\mathrm{T}_{12}$ had also similar yield $(24.42 \mathrm{~g})$. These results reflected the important effect of biofertilizers even with application of half $\mathrm{N}$ dose. Consequently, $T_{6}, T_{4}, T_{10}, T_{12}$ and $T_{11}$ for seed yield /fed $(\mathrm{kg})$; 1273.0, 1260.0, 1237.0, 1223.0 and 1158.0, respectively, due to its recognition in yield /plant were significantly high and surpassed control $\left(T_{13}\right)$ and other treatments. The results are in agreement with the findings of Gupta and Samnotra (2004) who concluded that simultaneous application of Azotobacter had a significant effect on yield of Brassica. $\mathrm{T}_{8}, \mathrm{~T}_{7}, \mathrm{~T}_{6}$ followed by $\mathrm{T}_{5}$ and $\mathrm{T}_{4}$ were recognize in protein content (\%); 26.27, 25.92, 25.90, 25.38 and 25.17. While treatments $\mathrm{T}_{12}$ and $_{11}$ for oil content (\%); 44.30 and 44.0 were high but insignificantly different from control. Superiority of the above mentioned treatments, especially $\mathrm{T}_{10}, \mathrm{~T}_{11}$ and $\mathrm{T}_{12}$ (received half amount of mineral nitrogen), were desirable owing to their relative advantages, little cost of fertilization and reduced pollution in newly reclaimed soils. Similar results were previously recorded by Yasari et al. (2008). In a conclusion $\mathrm{T}_{6}$ was superior in all studied characteristics except for number of branches/plant, seed index and oil percentage; while $\mathrm{T}_{4}$ surpassed all treatments in all traits except for plant height and oil percentage. It is interesting to note that, $\mathrm{T}_{10}$ showed superiority for all characteristics except for plant height 14Copyright @ 2010, Bioinfo Publications, International Journal of Agriculture Sciences, ISSN: 0975-3710, Volume 2, Issue 1, 2010 and yield quality. Both $T_{11}$ and $T_{12}$ were superior in all studied characteristics except for seed index and protein percentage.

\section{A. Effect of interaction between lines and fertilizers' combinations}

Data presented in Table (2) show that, for plant height, $L_{6} T_{12}, H_{2} T_{13}, L_{6} T_{13}, L_{6} T_{1}, L_{6} T_{6}, L_{6} T_{8}$, $\mathrm{L}_{6} \mathrm{~T}_{11}, \mathrm{~L}_{6} \mathrm{~T}_{7}, \mathrm{H}_{2} \mathrm{~T}_{8}, \mathrm{H}_{2} \mathrm{~T}_{4}$ and $\mathrm{H}_{2} \mathrm{~T}_{11}$ had tallest plants; 141.2, 138.2, 137.8, 137.8, 137.2, 136.8, 135.8, 134.8, 134.2, 134.2 and 134.2, respectively; $\mathrm{H}_{2} \mathrm{~T}_{10}(8.0), \mathrm{L}_{6} \mathrm{~T}_{2}(7.8), \mathrm{L}_{6} \mathrm{~T}_{6}(7.6)$, $\mathrm{H}_{2} \mathrm{~T}_{4}(7.4)$, followed by $\mathrm{L}_{6} \mathrm{~T}_{12}(7.0), \mathrm{H}_{2} \mathrm{~T}_{11}(6.9)$ and $L_{6} T_{9}(6.9)$ gave the greatest number of branches/plant. $\quad \mathrm{H}_{2} \mathrm{~T}_{10}(466.0), \quad \mathrm{L}_{6} \mathrm{~T}_{8}(438.0)$ possessed the highest number of pods/plant followed by $\mathrm{L}_{6} \mathrm{~T}_{6}(381.2)$ and $\mathrm{H}_{2} \mathrm{~T}_{4}(340.2)$; concerning seed yield /plant, $\mathrm{L}_{6} \mathrm{~T}_{8}$ (35.9), $\mathrm{H}_{2} \mathrm{~T}_{10}$ (35.3), $\quad \mathrm{H}_{2} \mathrm{~T}_{4}(33.25)$ and $\mathrm{L}_{6} \mathrm{~T}_{6}$ (32.29) produced the largest weights; $\mathrm{H}_{2} \mathrm{~T}_{3}, \mathrm{~L}_{6} \mathrm{~T}_{4}$, $\mathrm{H}_{2} \mathrm{~T}_{10}$, followed by $\mathrm{H}_{2} \mathrm{~T}_{9}$ and $\mathrm{H}_{2} \mathrm{~T}_{11}$ gave the heaviest seed index $(\mathrm{g}) ; 3.32,3.27,3.24,3.1$ and 3.08 , respectively. In regard to seed yield /feddan, $\mathrm{L}_{6} \mathrm{~T}_{1}(1338.0)$ and $\mathrm{L}_{6} \mathrm{~T}_{6}(1327.0 \mathrm{~kg})$, as well as $\mathrm{H}_{2} \mathrm{~T}_{4}(1327.0), \mathrm{H}_{2} \mathrm{~T}_{10}(1393.0)$ and $\mathrm{H}_{2} \mathrm{~T}_{11}(1318.0 \mathrm{~kg})$ produced the highest yields, followed by $L_{6} T_{2}$ (1296.0), $L_{6} T_{8}(1239.0)$, $\mathrm{H}_{2} \mathrm{~T}_{12}(1226.0), \quad \mathrm{L}_{6} \mathrm{~T}_{12}$ (1219.0), $\quad \mathrm{H}_{2} \mathrm{~T}_{6}(1218.0)$ and $L_{6} T_{4}(1194.0 \mathrm{~kg})$. These results revealed that again the importance of biofertilizers either with $L_{6}$ and $H_{2}$ lines. $L_{6} T_{8}, L_{6} T_{7}, H_{2} T_{6}, H_{2} T_{8}$ followed by, $\mathrm{L}_{6} T_{5}, \mathrm{H}_{2} \mathrm{~T}_{5}, \mathrm{H}_{2} \mathrm{~T}_{7}, \mathrm{~L}_{6} \mathrm{~T}_{6}, \mathrm{~L}_{6} \mathrm{~T}_{4}, \mathrm{H}_{2} \mathrm{~T}_{4}$, $\mathrm{H}_{2} T_{9}, L_{6} T_{9}$ and $L_{6} T_{11}$ gave the highest protein content percentage; 26.53, 26.50, 26.50, $26.02,25.38,25.38,25.33,25.30,25.22$ $25.12,25.03,24.88$ and 24.78 , respectively and $L_{6} T_{13}, H_{2} T_{12}, L_{6} T_{12}$, followed by $L_{6} T_{4}$, $H_{2} T_{13}, L_{6} T_{11}, H_{2} T_{11}, L_{6} T_{3}$ and $H_{2} T_{3}$ gave the highest oil percentage; 44.40, 44.40, 44.20, 44.07, 44.00, 44.00, 44.00, 43.97 and 43.92, respectively. The results are in agreement with the findings of Grami and La Croix (1977) and Yasari et al.(2008) in their study on canola; Suneja and Lakshminaraya (2001) on Indian mustard; Ozturk et al. (2003) on barley; Singh et al. (2005) on sorghum and Cecilia et al. (2004) on wheat. It could be concluded that $\mathrm{H}_{2} \mathrm{~T}_{10}$, was the best in all studied traits except for plant height, protein and oil percentages; $\mathrm{H}_{2} T_{4}, L_{6} T_{6}$ and $L_{6} T_{8}$ for all studied traits except for seed index and oil percentage. It's worth mentioning that the highest productivity of $\mathrm{H}_{2} \mathrm{~T}_{10} \quad\left(\mathrm{~N}_{2}+\right.$ Trichoderma +Azotobacter $), \mathrm{H}_{2} \mathrm{~T}_{11}$ $\left(\mathrm{N}_{2}+\right.$ Azotobacter + Azospirillum) and $\mathrm{L}_{6} \mathrm{~T}_{8}\left(\mathrm{~N}_{2}+\right.$ Azotobacter) was a result of using only $50 \%$ of the recommended dose of nitrogen fertilizer which in turn is an economic advantage.

\section{References}

[1] Bunt, J.S. and Rovira, A.D. (1955). Microbiological studies of some Antarctic soils. J. Soil Sci., 6: 199-228.

[2] Cecilia, M.C., Sueldo, R.J. and Barassi, C.A. (2004). Water relations and yield in Azosprillum - inoculated wheat 
exposed to drought in field. Can. J. Bot., 82: 373-281.

[3] Day, J.M. and Dobereiner, J. (1975). Physiological aspects of $\mathrm{N}_{2}$-fixation by Azospirillum from Digitaria roots. Soil Biol. Biochem., 8: 45-50.

[4] Ebrahimi, S., Naehad, H. I., Shirani Rad, A.H., Abbas Akbari, G. Amiry, R. and Modarres Sanavy, S.A.M. (2007). Effect of Azotobacter chroococcum application on quantity and quality forage of rapeseed cultivars. Pak. J, Bio. Sci., 10(18): 3126-3130.

[5] Freitas, J. R., Banerjee, M. R. and Germida, J. J. (1997). Phosphate solubilizing Rhizobacteria enhance the growth and yield but not phosphorus uptake of canola (Brassica napus L.). Biol. Fert. Soil, 24: 358-364.

[6] Ghallab, K.H. and Sharaan, A.N. (2002). Selection in canola (Brassica napus L.) germplasm under conditions of newly reclaimed land. II. Salt tolerant selections. Egypt. J. Plant Breed. 6(2): 15-30.

[7] Gomez, K.A. and A.A. Gomez (1984). Statistical Procedures for Agricultural Research. $2^{\text {nd }}$ Ed., John Wiley and Sons, New York, USA.

[8] Grami,B. and La Croix, L.J. (1977). Cultivar variation in total nitrogen uptake in rape, Can. J. Plant Sci. 57 (1977): 619-624.

[9] Gupta, A.K. and Samnotra, R.K. (2004). Effect of biofertilizers and nitrogen on growth, quality and yield of cabbage (Brassica napus). Environ. Ecol., 22: 551-553.

[10] Hegazi, N.A., Amer, H.A. and Monib, M. (1980). Studies on $\mathrm{N}_{2}$-fixing Spirilla (Azospirillum spp.) in Egyptian soils. Rev. Ecol. Biol. soil, 17: 491-499,

[11] Kandil, A.A. (1984). Preliminary study on the effect of NPK fertilization on the oil seed rape (Brassica napus L.). Res. Bull. No. 429, Fac. of Agric. Zagazig University.

[12] Khalid, A., Rashad, M. A. and Zahir, Z. A. (2004). Screening plant growth promoting Rhizobacteria for improving growth and yield of wheat. J. Applied Microbiol., 96: 473-480.

[13] Ozturk, A., Caglar, O. and Sahin, F. (2003). Yield response of wheat and barley to inoculation of plant growth promoting Rhizobacteria at various levels of nitrogen fertilizers. J. Plant Nutr. Soil Sci.,166: 262-266.

[14] Prasad, M. and Prasad, R. (2004). Effect of mepiquat chloride, Azotobacter and nitrogen on cotton (Gossypium hirsutum) and their residual effect on succeeding transplanted Indian mustard Brassica juncea. Indian J. Agric. Sci., 74: 273-275.

[15] Rodriguez, H., Gonzales, T., Goir, I. and Bashan, Y. (2004). Gluconic acid production and phosphate solubilization by the plant growthpromoting bacterium Azospirillum spp. Naturwissensechaften, 91: 552-555.

[16] Sharaan, A.N. (1986). Variation in character expression in rapeseed (Brassica napus L.) cultivars in relation to environmental changes. Bull. Fac. of Agric. Univ. of Cairo 37 (1): 35-48.

[17] Sharaan, A. N., Ghallab, K. H. and Yousif, K. M. (2002). Performance and water relations of some rapeseed genotypes grown in sandy loam soils under irrigation regimes. Annals of Agric. Sc., Moshtohor, 40(2): 751-767.

[18] Sharma, S. K., Rao, R. M. and Singh, D. P. (1997). Effect of crop geometry and nitrogen on quality and oil yield of Brassica species. Ind. J. Agron., 42: 357-360.

[19] Singh, M. M., Mautya, M. L. , Singh, S. P. and Mishra, C. H. (2005). Effect of nitrogen and biofertilizers inoculation on productivity of forage sorghum (Sorghum bicolor). Ind. J. Agric. Sci., 73: 167-168.

[20] Suneja, S. and Lakshminaraya, K. (2001). Isolation of siderophore negative mutants of Azotobacter chroococcum and studied on the role of siderophores in mustard yield. Ind. J. Plant Physiol., 6: 190-193.

[21] Weiss, E.W. (1983). Oilseed Crops. Longman, London \& New York. pp. 660.

[22] Yasari, E., Esmaeli Azadgoleh, A. M. , Pirdashti, H. and Mozafari, S. (2008). Azotobacter and Azospirllum inoculants as biofertilizers in canola (Brassica napus L.) cultivation. Asian J. Plant Sci., 7(5): 490-494.

[23] Yasari, E., Azadgoleh, M. A. E., Mozafari, S. and Alashti, M.R. (2009). Enhancement of growth and nutrient uptake of rapeseed (Brassica napus L.) by applying mineral nutrients and biofertilzers. Pak. J, Bio. Sci., 12(2): 127-133. 


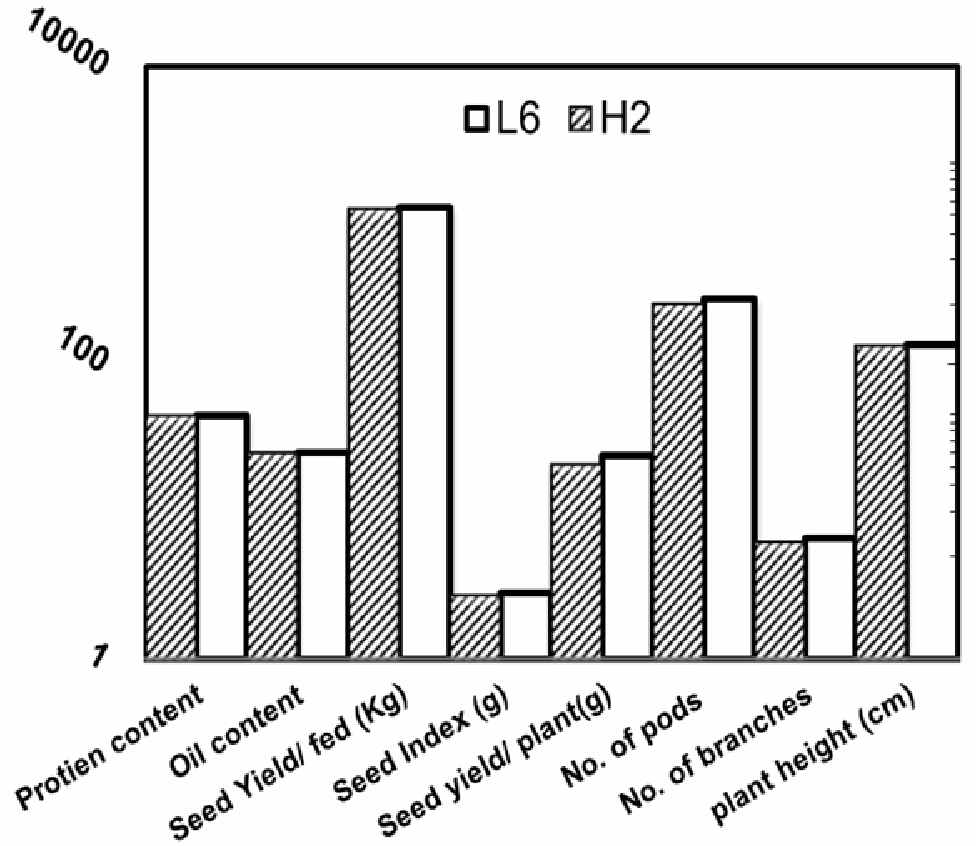

Fig. 1- Effect of lines on yield, its components and quality traits (over two seasons).

Table 1- Effect of applied different fertilizers' combinations on canola seed yield, yield components and quality traits over the two seasons.

\begin{tabular}{|c|c|c|c|c|c|c|c|c|}
\hline fertilizers' combinations & $\begin{array}{l}\text { plant } \\
\text { height } \\
(\mathrm{cm})\end{array}$ & $\begin{array}{l}\text { No. of } \\
\text { branches }\end{array}$ & $\begin{array}{l}\text { No. } \\
\text { pods }\end{array}$ & $\begin{array}{l}\text { Seed yield/ } \\
\text { plant }(\mathrm{g})\end{array}$ & $\begin{array}{l}\text { Seed } \\
\text { Index (g) }\end{array}$ & $\begin{array}{l}\text { Seed } \\
\text { Yield/ fed } \\
(\mathrm{Kg})\end{array}$ & Oil content & $\begin{array}{l}\text { Protein } \\
\text { content }\end{array}$ \\
\hline $\mathrm{N}_{1}+$ Tri. $\left(\mathrm{T}_{1}\right)$ & $131.4 \mathrm{bc}$ & 6.050def & $202.3 c$ & $21.77 \mathrm{bc}$ & $2.620 \mathrm{fg}$ & $1147.0 \mathrm{abc}$ & $43.75 d$ & $24.36 \mathrm{ef}$ \\
\hline $\mathrm{N}_{1}+$ Azot. $\left(\mathrm{T}_{2}\right)$ & $127.2 \mathrm{~cd}$ & $6.600 \mathrm{bc}$ & $244.1 \mathrm{bc}$ & $20.09 c$ & $2.967 \mathrm{bc}$ & $1073.0 \mathrm{cde}$ & $43.77 d$ & 24.31 ef \\
\hline $\mathrm{N}_{1}+$ Azosp. $\left(\mathrm{T}_{3}\right)$ & $121.6 \mathrm{e}$ & 5.950 ef & $197.7 c$ & $14.96 \mathrm{~d}$ & $3.138 a$ & $899.0 f$ & $43.94 \mathrm{bcd}$ & $24.25 \mathrm{f}$ \\
\hline $\mathrm{N}_{1}+$ Tri.+Azot. $\left(\mathrm{T}_{4}\right)$ & $131.5 b c$ & $6.850 a b$ & $313.6 a$ & $28.23 a$ & $3.148 a$ & $1260.0 a b$ & $43.98 \mathrm{bc}$ & $25.17 \mathrm{bc}$ \\
\hline $\mathrm{N}_{1}+$ Azot.+Azosp. $\left(\mathrm{T}_{5}\right)$ & $128.5 \mathrm{~cd}$ & $5.700 f$ & $197.9 c$ & $18.79 \mathrm{c}$ & $2.784 \mathrm{de}$ & 935.1 ef & $43.83 \mathrm{bcd}$ & $25.38 b$ \\
\hline $\mathrm{N}_{1}+$ Tri.+ Azot.+Azosp. $\left(\mathrm{T}_{6}\right)$ & $135.0 a b$ & $6.550 \mathrm{bcd}$ & $356.0 \mathrm{a}$ & $27.55 a$ & $2.469 \mathrm{~h}$ & $1273.0 \mathrm{a}$ & $43.55 \mathrm{e}$ & $25.90 a$ \\
\hline $\mathrm{N}_{2}+$ Tri. $\left(\mathrm{T}_{7}\right)$ & $128.8 \mathrm{~cd}$ & 6.200 cdef & $197.8 \mathrm{c}$ & $21.25 \mathrm{bc}$ & $2.253 i$ & 950.7 ef & $43.15 f$ & $25.92 \mathrm{a}$ \\
\hline $\mathrm{N}_{2}+$ Azot. $\left(\mathrm{T}_{8}\right)$ & $135.5 a b$ & $6.500 \mathrm{bcd}$ & $340.0 a$ & $26.05 a$ & 2.709ef & 1112.0bcd & $43.06 \mathrm{fg}$ & $26.27 a$ \\
\hline $\mathrm{N}_{2}+$ Azosp. $\left(\mathrm{T}_{9}\right)$ & 125.6de & 6.400bcde & $240.0 \mathrm{bc}$ & $21.23 \mathrm{bc}$ & $2.911 \mathrm{~cd}$ & $953.9 \mathrm{ef}$ & $42.95 \mathrm{~g}$ & $24.96 \mathrm{~cd}$ \\
\hline $\mathrm{N}_{2}+$ Tri. + Azot. $\left(\mathrm{T}_{10}\right)$ & $125.7 \mathrm{de}$ & $7.200 a$ & $355.2 a$ & $26.81 a$ & $3.086 a b$ & $1237.0 \mathrm{ab}$ & $43.79 \mathrm{~cd}$ & 24.58 def \\
\hline $\mathrm{N}_{2}+$ Azot.+Azosp. $\left(\mathrm{T}_{11}\right)$ & $135.0 \mathrm{ab}$ & $6.800 a b$ & $209.5 b c$ & $21.44 \mathrm{bc}$ & $2.983 b c$ & 1158.0abc & $44.00 a b$ & 24.68de \\
\hline $\mathrm{N}_{2}+$ Tri. + Azot.+Azosp. $\left(\mathrm{T}_{12}\right)$ & 136.2ab & $6.700 a b c$ & $252.0 \mathrm{~b}$ & $24.42 a b$ & $2.626 f g$ & $1223.0 a b$ & $44.30 \mathrm{a}$ & $24.54 \mathrm{ef}$ \\
\hline Control $\left(T_{13}\right)$ & $138.0 \mathrm{a}$ & 5.900 ef & $225.4 \mathrm{bc}$ & $12.91 d$ & $2.557 \mathrm{gh}$ & 1001.0def & $44.20 \mathrm{a}$ & $24.41 \mathrm{ef}$ \\
\hline
\end{tabular}

Mean followed by the same letter(s) in each column are not significantly different (Duncan multiple range test $5 \%$ ) 
Table 2- Effect of interaction between lines and different fertilizers' combinations on canola seed yield, yield components and quality traits over the two seasons.

\begin{tabular}{|c|c|c|c|c|c|c|c|c|}
\hline $\begin{array}{l}\text { Lines } \quad X \quad \text { fertilizers' } \\
\text { combinations }\end{array}$ & $\begin{array}{l}\text { plant } \\
\text { height } \\
(\mathrm{cm})\end{array}$ & $\begin{array}{l}\text { No. of } \\
\text { branches }\end{array}$ & $\begin{array}{ll}\text { No. } & \text { of } \\
\text { pods }\end{array}$ & $\begin{array}{l}\text { Seed yield/ } \\
\text { plant }(\mathrm{g})\end{array}$ & $\begin{array}{l}\text { Seed Index } \\
\text { (g) }\end{array}$ & $\begin{array}{l}\text { Seed Yield/ } \\
\text { fed }(\mathrm{Kg})\end{array}$ & $\begin{array}{l}\text { Oil } \\
\text { content }\end{array}$ & $\begin{array}{l}\text { Protein } \\
\text { content }\end{array}$ \\
\hline $\mathrm{L}_{6} \times \mathrm{T}_{1}\left(\mathrm{~N}_{1}+\mathrm{Tri}.\right)$ & 137.8ab & 6.300defg & 228.0fghi & $28.52 b c$ & 2.790ghijk & $1338.0 \mathrm{a}$ & 43.70def & 24.68defghi \\
\hline $\mathrm{L}_{6} \times \mathrm{T}_{2}\left(\mathrm{~N}_{1}+\right.$ Azot. $)$ & 133.2bcd & $7.800 \mathrm{a}$ & $320.8 \mathrm{~cd}$ & $26.10 \mathrm{cde}$ & 3.007defg & 1269.0ab & 43.70def & $23.90 \mathrm{k}$ \\
\hline $\mathrm{L}_{6} \times \mathrm{T}_{3}\left(\mathrm{~N}_{1}+\right.$ Azosp. $)$ & 123.2fgh & $5.900 \mathrm{ghi}$ & 186.0hi & $13.50 \mathrm{kl}$ & 2.957defgh & $946.7 f$ & $43.97 \mathrm{bcd}$ & 24.12ijk \\
\hline $\mathrm{L}_{6} \times \mathrm{T}_{4}\left(\mathrm{~N}_{1}+\right.$ Tri.+Azot. $)$ & 128.8cdefg & 6.300defg & 287.0def & 23.22cdefg & 3.270ab & 1194.0abcde & $44.07 \mathrm{bc}$ & 25.22bcde \\
\hline $\mathrm{L}_{6} \times \mathrm{T}_{5}\left(\mathrm{~N}_{1}+\right.$ Azot. + Azosp. $)$ & 129.0cdefg & $5.700 \mathrm{ghi}$ & 209.0ghi & 17.00hijk & 2.842fghij & $941.2 f$ & $43.87 \mathrm{cde}$ & $25.38 b$ \\
\hline $\begin{array}{llll}\text { L6 } & x & T_{6} & \left(N_{1}+\text { Tri.+ }\right. \\
\text { Azot.+Azosp. }) & \\
\end{array}$ & 137.2ab & 7.600ab & $381.2 \mathrm{bc}$ & 32.12ab & $2.607 \mathrm{klm}$ & 1327.0a & 43.63efg & $25.30 \mathrm{bcd}$ \\
\hline $\mathrm{L}_{6} \times \mathrm{T}_{7}\left(\mathrm{~N}_{2}+\mathrm{Tri}.\right)$ & 134.8abcd & 6.500defg & 227.8fghi & 24.17cdef & 2.2700 & 976.3ef & $43.40 \mathrm{~g}$ & $26.50 \mathrm{a}$ \\
\hline $\mathrm{L}_{6} \times \mathrm{T}_{8}\left(\mathrm{~N}_{2}+\right.$ Azot. $)$ & $136.8 \mathrm{ab}$ & 6.200efgh & 438.0ab & $35.90 a$ & 2.852efghij & 1239.0abc & $42.72 \mathrm{i}$ & $26.53 a$ \\
\hline $\mathrm{L}_{6} \times \mathrm{T}_{9}\left(\mathrm{~N}_{2}+\right.$ Azosp. $)$ & 131.2bcde & $6.900 \mathrm{bcde}$ & 208.7ghi & 17.60ghijk & 2.720ijkl & $866.2 f$ & $42.90 \mathrm{hi}$ & 24.88bcdefg \\
\hline $\mathrm{L}_{6} \times \mathrm{T}_{10}\left(\mathrm{~N}_{2}+\right.$ Tri. + Azot. $)$ & 122.2gh & 6.400defg & 244.3efgh & 18.32ghijk & 2.932defghi & 1081.0bcdef & 43.70def & 24.53fghij \\
\hline $\mathrm{L}_{6} \times \mathrm{T}_{11}\left(\mathrm{~N}_{2}+\right.$ Azot.+Azosp. $)$ & $135.8 a b c$ & 6.700cdef & 222.0fghi & $23.08 \mathrm{cdefg}$ & 2.887defghij & 998.7def & $44.00 \mathrm{bcd}$ & 24.78bcdefgh \\
\hline $\begin{array}{llll}\mathrm{L}_{6} \quad \mathrm{x} & \mathrm{T}_{12} & \left(\mathrm{~N}_{2}+\text { Tri.+ }\right. \\
\text { Azot. }+ \text { Azosp. }) & \\
\end{array}$ & $141.2 a$ & $7.000 \mathrm{bcd}$ & 302.0de & $26.53 \mathrm{~cd}$ & 2.732hijkl & 1219.0abcd & $44.20 \mathrm{ab}$ & 24.70defghi \\
\hline $\begin{array}{l}\mathrm{L}_{6} \times \mathrm{T}_{13} \\
\text { (control) }\end{array}$ & 137.8ab & 5.800ghi & 238.2efghi & 15.43ijkl & $2.427 \mathrm{mno}$ & 1002.0ef & $44.40 a$ & 24.18hijk \\
\hline $\mathrm{H}_{2} \times \mathrm{T}_{1}\left(\mathrm{~N}_{1}+\right.$ Tri. $)$ & 125.0efgh & $5.800 \mathrm{ghi}$ & 176.7hi & 15.03ijkl & $2.450 \mathrm{mno}$ & $956.7 f$ & $43.80 \mathrm{cde}$ & 24.03jk \\
\hline $\mathrm{H}_{2} \times \mathrm{T}_{2}\left(\mathrm{~N}_{1}+\right.$ Azot. $)$ & $121.2 \mathrm{~h}$ & $5.400 \mathrm{i}$ & $167.3 i$ & 14.08jkl & 2.927defghi & $877.2 f$ & $43.83 \mathrm{cde}$ & 24.72defghi \\
\hline $\mathrm{H}_{2} \times \mathrm{T}_{3}\left(\mathrm{~N}_{1}+\right.$ Azosp. $)$ & 120.0h & 6.000fghi & 209.3ghi & 16.42ijk & $3.320 a$ & $851.3 f$ & $43.92 \mathrm{bcde}$ & 24.38ghijk \\
\hline $\mathrm{H}_{2} \times \mathrm{T}_{4}\left(\mathrm{~N}_{1}+\right.$ Tri.+Azot. $)$ & 134.2abcd & $7.400 \mathrm{abc}$ & $340.2 \mathrm{~cd}$ & 33.23ab & 3.027cdef & $1327.0 \mathrm{a}$ & $43.90 \mathrm{cde}$ & $25.12 \mathrm{bcdef}$ \\
\hline $\mathrm{H}_{2} \times \mathrm{T}_{5}\left(\mathrm{~N}_{1}+\right.$ Azot.+Azosp. $)$ & 128.0defg & $5.700 \mathrm{ghi}$ & 186.9hi & 20.58efghi & 2.727hijkl & 929.0f & $43.80 \mathrm{cde}$ & $25.38 b$ \\
\hline $\begin{array}{llll}\mathrm{H}_{2} \quad \mathrm{x} & \mathrm{T}_{6} & \left(\mathrm{~N}_{1}+\text { Tri.+ }\right. \\
\text { Azot.+Azosp. }) & \\
\end{array}$ & $132.8 \mathrm{bcd}$ & 5.500hi & $330.8 \mathrm{~cd}$ & 22.98cdefg & $2.332 \mathrm{no}$ & 1218.0abcd & $43.47 \mathrm{fg}$ & $26.50 a$ \\
\hline $\mathrm{H}_{2} \times \mathrm{T}_{7}\left(\mathrm{~N}_{2}+\right.$ Tri. $)$ & 122.8fgh & 5.900ghi & $167.8 \mathrm{i}$ & 18.33ghijk & 2.2370 & 925.0f & $42.90 \mathrm{hi}$ & $25.30 \mathrm{bc}$ \\
\hline $\mathrm{H}_{2} \times \mathrm{T}_{8}\left(\mathrm{~N}_{2}+\right.$ Azot. $)$ & 134.2abcd & $6.800 \mathrm{cde}$ & 242.0efghi & 16.19ijk & $2.567 \mathrm{klm}$ & 984.0ef & $43.40 \mathrm{~g}$ & $26.02 \mathrm{a}$ \\
\hline $\mathrm{H}_{2} \times \mathrm{T}_{9}\left(\mathrm{~N}_{2}+\right.$ Azosp. $)$ & 120.0h & 5.900ghi & 271.3defg & 24.87cdef & 3.102bcd & 1042.0cdef & $43.00 \mathrm{~h}$ & 25.03bcdef \\
\hline $\mathrm{H}_{2} \times \mathrm{T}_{10}\left(\mathrm{~N}_{2}+\right.$ Tri.+Azot. $)$ & 129.2cdef & $8.000 \mathrm{a}$ & $466.0 \mathrm{a}$ & $35.30 \mathrm{a}$ & $3.240 \mathrm{abc}$ & $1393.0 \mathrm{a}$ & $43.88 \mathrm{cde}$ & 24.62efghij \\
\hline $\begin{array}{ll}\mathrm{H}_{2} \quad \mathrm{x} & \mathrm{T}_{11} \\
\left(\mathrm{~N}_{2}+\text { Azot. }+ \text { Azosp. }\right) & \\
\end{array}$ & 134.2abcd & $6.900 \mathrm{bcde}$ & 197.0hi & 19.80fghij & 3.080bcde & $1318.0 \mathrm{a}$ & $44.00 \mathrm{bcd}$ & 24.58fghij \\
\hline $\begin{array}{lll}\mathrm{H}_{2} \quad \mathrm{x} & \mathrm{T}_{12} & \left(\mathrm{~N}_{2}+\text { Tri.+ }\right. \\
\text { Azot. }+ \text { Azosp. }) & \\
\end{array}$ & 131.2bcde & 6.400defg & 202.0ghi & 22.32defgh & $2.5201 \mathrm{mn}$ & 1226.0abc & $44.40 \mathrm{a}$ & 24.38ghijk \\
\hline $\mathrm{H}_{2} \times \mathrm{T}_{13}$ (control) & 138.2ab & 6.000fghi & 212.7ghi & 10.391 & 2.687jkl & 1000.0ef & $44.00 \mathrm{bcd}$ & 24.63efghij \\
\hline
\end{tabular}

Mean followed by the same letter(s) in each column are not significantly different (Duncan multiple range test $5 \%$ ) 